\title{
KEPRIBADIAN, MOTIVASI, DAN PERILAKU KOMPLAIN BERDASARKAN SUKU
}

\author{
Dwi Wandani ${ }^{1}$, Megawati Simanjuntak ${ }^{1^{*}}$ \\ ${ }^{1}$ Departemen IImu Keluarga dan Konsumen, Fakultas Ekologi Manusia, Institut Pertanian Bogor, \\ Bogor 16680, Indonesia \\ ${ }^{*}$ E-mail: mega_juntak@apps.ipb.ac.id
}

\begin{abstract}
Abstrak
Perilaku komplain yang dilakukan konsumen merupakan hal yang penting untuk mengungkapkan rasa ketidakpuasannya terhadap barang dan/atau jasa yang dikonsumsinya. Penelitian ini bertujuan menganalisis pengaruh kepribadian dan motivasi terhadap perilaku komplain berdasarkan suku. Desain penelitian ini menggunakan studi kuantitatif dan cross-sectional dengan metode survei daring. Teknik penarikan contoh dipilih secara purposive sampling, dengan responden mahasiswa sebanyak 286 orang. Analisis data menggunakan metode Structural Equation Modelling (SEM) melalui program Analysis of Moment Structures (AMOS) dan Smart Partial Least Square (PLS) dan uji beda One Way Anova. Hasil penelitian responden dari ketiga suku yaitu Suku Jawa, Suku Batak, dan Suku Bugis menggambarkan kepribadian ekstrover yang memiliki proporsi paling tinggi, motivasi terkategori sedang yang artinya masih cukup baik dan perlu ditingkatkan kembali. Sementara perilaku komplain masih terkategori rendah. Hasil penelitian menunjukkan adanya perbedaan nyata antara Suku Jawa dan Suku Batak dalam melakukan perilaku komplain. Berdasarkan uji pengaruh menggunakan SEM, terdapat pengaruh signifikan kepribadian terhadap perilaku komplain Suku Bugis dan terdapat pengaruh signifikan antara motivasi dengan perilaku komplain pada Suku Jawa.
\end{abstract}

Kata kunci : kepribadian, motivasi, perilaku komplain, suku, Structural Equation Modelling (SEM)

\section{Personality, Motivation, and Complaints Behavior based on Ethnicity}

\begin{abstract}
The behavior of complaints is an important issue so that consumers can express their dissatisfaction to the consumption of goods and/or services. This study aims to analyze personality and motivation on complaint behavior based on ethnicity. The design of this study used quantitative and cross-sectional studies with online survey methods. Respondents were selected by purposive sampling techniques and involved 286 college students as participants. Data analysis used the SEM method through Analysis of Moment Structures (AMOS) and Smart Partial Least Square (PLS) programs and one way ANOVA difference tests. The result respondents from the three ethnic groups namely Javanese, Batak, and Bugis describe the extrovert personality is the highest proportion of personality amongs three tribes, the highest proportion of respondents among three tribes is moderate category of motivation. However, the result also revealed that the complaint behavior from respondents among three tribes is categorized as low. The results showed that there were significant differences between Javanese and Bataknese in carrying out complaints. Based on the influence test using the SEM, there is a significant influence of personality on the complaint behavior of the Bugis ethnic and there is a significant influence of motivation on complaint behavior on the Javanese.
\end{abstract}

Keywords: complaint behavior, ethnicity, motivation, personality, Structural Equation Modelling (SEM)

\section{PENDAHULUAN}

Perilaku komplain menjadi bagian yang penting bagi konsumen untuk menyampaikan keluhan dan ketidakpuasannya serta sebagai perwujudan kesadaran yang tinggi akan hak konsumen. Konsumen yang merasa tidak puas terhadap barang dan/atau jasa akan menyampaikannya dengan berbagai cara, diantaranya dengan melakukan perilaku komplain (Blodgett, Bakir, \& Saklai, 2015). Perilaku komplain juga merupakan suatu hal yang baik bagi pelaku usaha. Melalui komplain, pelaku usaha dapat memperbaiki kekurangannya dan dapat meningkatkan kualitas dan semakin dapat memberikan kepuasan bagi konsumen. Meskipun hasil riset Simanjuntak dan Hamimi (2019), penanganan komplain yang dilakukan pelaku usaha masih tergolong rendah. Komplain terhadap pelaku usaha tidak hanya dapat dilakukan secara manual dengan menghampiri toko atau tempat penjualan secara langsung. Berbagai pelaku usaha ada yang sudah membuka saluran 
komplain secara daring melalui situs internet (website) atau media sosial untuk menyesuaikan dengan teknologi dan kebutuhan generasi Z (Priporas, Stylos, \& Fotiadis, 2017). Sebagai salah satu generasi paling muda, generasi Z membutuhkan informasi terkait komplain yang lebih mudah secara online untuk dapat memperoleh informasi produk berupa barang dan/atau jasa dengan mudah dan cepat melalui media gadget dan media sosial yang dimiliki.

Perilaku komplain konsumen dapat dipengaruhi oleh kepribadian konsumen (Keng, 2015). Menurut Ekinci, Calderon dan Siala (2015), kepribadian, sifat, kesadaran, dan keterbukaan terhadap pengalaman memiliki hubungan yang signifikan dengan perilaku komplain konsumen. Temuan ini memberikan penguatan bahwa ciri kepribadian dapat menjadi prediktor potensial untuk perilaku komplain. Kepribadian merupakan sifat dan karakteristik individu yang berkontribusi dalam membedakan perilaku, konsistensi perilaku dalam waktu yang berbeda, dan stabilitas perilaku dalam berbagai situasi. Jika dibedakan berdasarkan tipe kepribadian ekstrover dan introver, pengguna media sosial dengan tipe kepribadian introver tidak mudah mengekspresikan serta menyatakan pikiran dan perasaannya di media sosial, berbeda dengan tipe ekstrover yang lebih mudah membagi informasi pribadinya (Cahyaning \& Cahyono, 2015). Hasil riset Simanjuntak (2019) mendukung pernyataan Cahyaning dan Cahyono (2015) banyak media sosial akan mengakibatkan perilaku komplain meningkat. Banyaknya media sosial ini sejalan dengan kepribadian ekstrovert.

Ketika konsumen melakukan komplain maka akan melibatkan motivasi pula. Motivasi menentukan cara konsumen menyampaikan komplain yang sesuai dengan ciri atau atribut yang ada dalam dirinya. Konsumen yang memiliki motivasi untuk komplain akan melakukan komplain berdasarkan ciri dalam diri atau biasa disebut dengan kepribadian (Sumarwan, 2014). Konsumen membeli barang dan/atau jasa menyesuaikan dengan kebutuhan berdasarkan motivasi yang dimiliki. Oleh karenanya, dalam melakukan tindakan komplain, konsumen akan memperjuangkan suatu kebutuhan yang seharusnya didapatkan karena jika tidak dilakukan, konsumen tersebut tidak akan mendapatkan barang dan/atau jasa yang sesuai (Nimako \& Mensah, 2012). Selain itu, konsumen melakukan perilaku komplain juga dapat dikaitkan dengan budaya dan lingkungan sekitarnya. Menurut Briones, Cockx dan Swinnen (2018), budaya adalah ketika sebagian besar masyarakat tersebut memiliki pemahaman yang sama mengenai suatu makna. Pentingnya melakukan komplain akan dimaknai berbeda pada setiap suku budaya tertentu. Ketika melakukan komplain, setiap budaya akan memberikan pemahaman yang berbeda. Sebagai gambaran, budaya Jawa khususnya masyarakat Provinsi Jawa Tengah cenderung lebih halus dalam menyampaikan sesuatu dan dikemas secara implisit, sementara masyarakat Suku Bugis dan Batak cenderung lebih speak up dan menyampaikan secara eksplisit. Perbedaan latar belakang suku dan faktor pencirinya akan berdampak dalam memotivasi diri untuk komplain dan dalam melakukan perilaku komplain (Thogersen, Juhl \& Poulsen 2003). Komplain konsumen melalui keluhan dapat memberikan dampak baik bagi perusahaan sehingga dapat memperbaiki barang produksi atau kinerja. Meskipun hasil riset Simanjuntak (2015) dan Simanjuntak dan Putri (2018) perilaku komplain konsumen masih rendah.

Hasil penelitian Metehan dan Yasemin (2011) menggambarkan bahwa karakteristik demografi dan tingkat pendidikan memiliki pengaruh positif terhadap perilaku komplain terhadap masyarakat Turki. Macam-macam suku/budaya dari demografi Turki memengaruhi konsumen dalam melanjutkan keluhannya ketika mengalami ketidakpuasan, semakin tinggi tingkat pendidikan juga memengaruhi konsumen untuk berjuang melakukan komplain. Thogersen, Juhl dan Poulsen (2003) menyatakan bahwa sikap dan kepribadian memiliki pengaruh kuat terhadap perilaku komplain. Penelitian Hartoyo, Tinaprila dan Prasetyo (2016) menyebutkan pengelompokan perilaku komplain menjadi empat kelompok yaitu private, voicers, irates, dan activist. Sementara menurut lliyola dan Ibiduni (2013), emosi negatif konsumen mendorong konsumen untuk melakukan perilaku komplain word of mouth negatif. Blodgett, Bakir dan Saklai (2015) dalam penelitiannya menunjukkan bahwa sikap dan tingkat kepentingan produk memengaruhi perilaku komplain. Penelitian selanjutnya, menurut Putra dan Giantari (2015) menemukan pengaruh sikap dan jenis kelamin terhadap perilaku komplain. Perempuan dinilai lebih kuat untuk melakukan pengaduan komplain dibandingkan dengan laki-laki ketika mengalami ketidakpuasan pasca-pembelian.

Fokus kajian penelitian ini yakni menganalisis faktor kepribadian, motivasi, dan latar 
belakang suku terhadap perilaku komplain konsumen. Motivasi dan kepribadian diduga akan memengaruhi perilaku komplain konsumen.Berdasarkan uraian di atas, hal yang membedakan dengan penelitian sebelumnya adalah penelitian komplain konsumen berdasarkan tiga suku yakni Suku Jawa (Jawa Tengah), Batak, dan Bugis yang belum pernah dilakukan sebelumnya. Tujuan dari penelitian ini yaitu menganalisis perbedaan kepribadian, motivasi, dan perilaku komplain berdasarkan suku; menganalisis pengaruh kepribadian terhadap motivasi komplain berdasarkan suku; dan menganalisis pengaruh kepribadian dan motivasi terhadap perilaku komplain berdasarkan suku.

\section{METODE}

Penelitian ini menggunakan desain cross sectional study. Populasi dalam penelitian ini adalah seluruh mahasiswa sebagai konsumen yang berasal dari Suku Batak, Bugis, dan Jawa. Contoh dalam penelitian ini adalah mahasiswa yang berasal dari Suku Jawa, Batak, dan Bugis dari usia 20 sampai 22 tahun dan pernah melakukan pembelian serta pernah merasa kecewa dan sempat melakukan komplain dalam satu tahun terakhir. Penentuan responden dalam penelitian ini dilakukan secara purposive berdasarkan persyaratan yang telah dijelaskan sebelumnya.

Ferdinand (2005) mengemukakan bahwa penentuan jumlah sampel untuk analisis Structural Equation Modelling (SEM) menggunakan rumus jumlah indikator dikalikan lima sampai sepuluh. Total pertanyaan/pernyataan dalam instrumen pengukuran sebanyak 57 pertanyaan/pernyataan dikali lima sehingga jumlah responden sebanyak 285 orang yang dipilih secara convenience sampling. Proporsi pengambilan data setiap suku berbeda, bergantung kepada peringkat suku terbanyak di Indonesia melalui data Badan Pusat Statistik (BPS). Berdasarkan data tersebut maka sebanyak 168 responden $(58,4 \%)$ diambil dari Suku Jawa, 80 responden $(28,3 \%)$ diambil dari Suku Batak dan 36 responden (13,3\%) diambil dari Suku Bugis.

Data primer diperoleh melalui survei daring untuk mengukur kepribadian, motivasi, dan perilaku komplain dari ketiga suku. Pengambilan data secara daring yakni tautan atau link berisi kuesioner yang sudah dibuat melalui google form selanjutnya disebar melalui media sosial seperti Line dan
Whatsapp kepada mahasiswa Suku Bugis, Batak, dan Jawa seluruh Indonesia yang pernah mengalami permasalahan atau kekecewaan ketika mengonsumsi barang dan/atau jasa.

Kepribadian konsumen diukur dengan instrumen EPQ- $R$ (Eysenck Personality Quetionnaire-Revision) sebanyak 12 pertanyaan. Instrumen tersebut dapat mengukur kepribadian ekstrover dan introver. Skor penilaian kepribadian menggunakan skala Guttman dengan skor 0 (tidak) dan 1 (ya) dengan nilai reliabilitas sebesar 0,709. Kepribadian adalah karakteristik dalam diri responden dan terdiri atas kepribadian ekstrover dan introver. Setiap manusia memiliki kepribadian yang mendominasi. Introver adalah tipe kepribadian yang cenderung lebih tertutup, individualis, dan pendiam. Ekstrover adalah tipe kepribadian yang terbuka, suka keramaian, senang berkumpul, dan lebih banyak bicara dibandingkan kepribadian introver. Kecenderungan responden memiliki kepribadian ekstrover atau introver, dilihat dari persentase jawaban. Apabila lebih dari 60 persen maka termasuk kedalam ekstrover dan di bawah 60 persen masuk kedalam kategori introver.

Motivasi diukur dengan pengisian salah satu kolom yang sesuai dengan motivasi contoh. Instrumen motivasi konsumen meliputi pernyataan mengenai motivasi menurut Heung dan Lam (2003) dengan lima pernyataan dan dikolaborasi dengan instrumen motivasi menurut Nimako dan Mensah (2012) sebanyak tujuh pernyataan, sehingga total pernyataan sebanyak 12. Pengukuran motivasi berbentuk skala Likert dan mempunyai rentang jawaban dari skor 1 (sangat tidak setuju), 2 (tidak setuju), 3 (antara setuju dan tidak setuju), 4 (setuju), sampai 5 (sangat setuju). Nilai reliabilitas instrumen motivasi yakni sebesar 0,791 . Motivasi dalam penelitian ini merujuk pada keinginan dalam diri responden untuk menyampaikan keluhannya akibat perasaan ketidakpuasan terhadap barang dan/atau jasa yang telah dikonsumsi.

Perilaku komplain diukur menggunakan instrumen Consumer Complaint Behavior (CCB) yang dikembangkan Singh (1988) yang terdiri atas 10 pertanyaan; 3 pertanyaan dimensi voice, 3 pertanyaan dimensi private response, dan 4 pertanyaan dimensi third party response. Instrumen tersebut dikombinasikan dengan instrumen yang dikembangkan oleh Musyrifah (2015) sehingga 
jumlah total pernyataan menjadi 16 . Ketiga dimensi ini bukan merupakan tingkatan, namun dimensi yang membentuk perilaku komplain. Pengukuran kuesioner untuk mengukur perilaku komplain berbentuk skala jawaban Likert dan mempunyai rentang jawaban dari skor 1 (sangat tidak setuju), 2 (tidak setuju), 3 (antara setuju dan tidak setuju), 4 (setuju), sampai 5 (sangat setuju). Nilai reliabilitas instrumen perilaku komplain yakni sebesar 0,618 . Perilaku komplain adalah seberapa sering responden melakukan komplain kepada pelaku usaha terkait kerugian pembelian yang dialami. Voice adalah perilaku komplain responden yang secara berani bersedia menyampaikan ketidakpuasannya kepada pelaku usaha secara langsung untuk meminta ganti rugi berupa pengembalian uang, penukaran barang, atau perbaikan (konsumen melakukan keluhan kepada pelaku usaha langsung). Private response adalah perilaku komplain yang dilakukan responden ketika mengalami ketidakpuasan, responden akan memberitahukannya kepada pihak lain seperti kerabat, teman, dan keluarga atas kekecewaannya ketika mengonsumsi suatu barang dan/atau jasa (konsumen menyebarkan ketidakpuasannya kepada orang lain). Third party response adalah perilaku komplain responden yang mengadukan perasaan ketidakpuasan atau kekecewaannya kepada lembaga yang berwenang menangani hal tersebut (konsumen mengadukan kecurangan pelaku usaha kepada pihak berwenang).

Data yang telah diperoleh diolah melalui proses editing, coding, input, cleaning, dan juga analisis data. Data dianalisis dengan menggunakan analisis deskriptif dan analisis inferensia. Pengolahan data dilakukan dengan menggunakan program software Microsoft Excel dan dianalisis menggunakan metode SEM (Structural Equation Modelling) melalui aplikasi program AMOS (Analysis of Moment Structures). Analisis SEM digunakan untuk setiap kelompok suku dan total responden. Untuk menganalisis kelompok Suku Jawa (168 responden) dan keseluruhan responden (286 responden) digunakan AMOS, sedangkan untuk menganalisis responden dibawah 100 yakni pada Suku Batak (80 responden) dan Suku Bugis (36 responden) digunakan Smart PLS (Partial Least Square). Uji beda one way ANOVA menggunakan program software SPSS (Statistical Package for Social Science) untuk menganalisis perbedaan kepribadian, motivasi dan perilaku komplain antar kelompok suku.

\section{HASIL}

\section{Karakteristik Responden}

Jenis Kelamin. Responden dalam penelitian secara keseluruhan didominasi oleh jenis kelamin perempuan $(68,9 \%)$. Apabila dibandingkan antarsuku asal responden, sebanyak tujuh dari sepuluh responden Suku Jawa berjenis kelamin perempuan $(72,0 \%)$; 67,5 persen responden Suku Batak berjenis kelamin perempuan; dan lebih dari separuh responden Suku Bugis berjenis kelamin perempuan $(57,9 \%)$.

Usia. Secara umum, hampir separuh $(46,5 \%)$ responden berusia 21 tahun. Usia responden terbanyak pada Suku Jawa adalah berada pada usia 21 tahun yakni sebanyak 45,2 persen. Begitu pula pada Suku Batak $(51,3 \%)$ yang proporsi terbesar juga berada pada usia 21 tahun. Sementara itu, dengan proporsi terbesar juga, 42,1 persen Suku Bugis juga berada pada usia 21 tahun.

Uang Saku. Hasil menunjukkan bahwa uang saku terbanyak yang dimiliki responden secara umum berkisar satu sampai dua juta per bulan $(47,2 \%)$. Berdasarkan suku asal responden, proporsi terbesar juga pada kisaran satu juta sampai dua juta rupiah per bulan yaitu 48,8 persen di Suku Jawa, 4,13 persen di Suku Batak, dan 52,6 persen di Suku Bugis.

Indeks Prestasi Kumulatif (IPK). Karakteristik responden berdasarkan IPK menunjukkan bahwa lebih dari tiga perempat responden Suku Jawa memiliki IPK diatas 3,50 (77,9\%); 63,7 persen responden Suku Batak memiliki IPK 2,76 sampai 3,50; dan 52,6\% responden dari Suku Bugis memiliki IPK antara 2,76 sampai 3,50. Berdasarkan data keseluruhan, lebih dari separuh (56,3\%) responden dalam penelitian ini memiliki IPK antara 2,76 sampai dengan 3,75 .

Tabel 1 Sebaran dan analisis deskriptif kepribadian berdasarkan suku

\begin{tabular}{ccccc}
\hline Suku & $\begin{array}{c}\text { Introver } \\
(\%)\end{array}$ & $\begin{array}{c}\text { Ekstrover } \\
(\%)\end{array}$ & $\begin{array}{c}\text { Rataan } \\
\pm \mathrm{SD}\end{array}$ & \multicolumn{1}{c}{$\begin{array}{c}\text { Min- } \\
\text { Max }\end{array}$} \\
\hline Jawa & 23,2 & 76,8 & $74,65 \pm$ & $16,67-$ \\
& & & 18,74 & 100,00 \\
Batak & 36,3 & 63,8 & $69,06 \pm$ & $8,33-$ \\
& & & 24,71 & 100,00 \\
Bugis & 15,8 & 84,2 & $76,31 \pm$ & $33,3-$ \\
& & & 15,92 & 100,00 \\
\hline
\end{tabular}


Tabel 2 Sebaran dan analisis deskriptif motivasi berdasarkan suku

\begin{tabular}{llccccc}
\hline Variabel & Suku & Rendah $(\%)$ & Sedang $(\%)$ & Tinggi $(\%)$ & Rataan \pm SD & Min-Max \\
\hline Motivasi komplain & Jawa & 32,1 & 57,1 & 10,7 & $63,09 \pm 17,32$ & $0,00-100,00$ \\
& Batak & 35,0 & 56,3 & 8,8 & $62,50 \pm 16,10$ & $0,00-100,00$ \\
\multirow{4}{*}{ Motivasi tidak komplain } & Bugis & 28,9 & 60,5 & 10,5 & $65,56 \pm 19,11$ & $0,00-93,33$ \\
& Jawa & 90,5 & 8,9 & 0,6 & $32,68 \pm 18,53$ & $0,00-93,33$ \\
& Batak & 92,5 & 6,3 & 1,3 & $33,33 \pm 16,19$ & $0,00-83,33$ \\
\multirow{4}{*}{ Motivasi } & Bugis & 94,7 & 5,3 & 0,0 & $31,67 \pm 17,98$ & $0,00-76,67$ \\
& Jawa & 27,4 & 56,5 & 16,1 & $65,92 \pm 15,28$ & $22,22-100,00$ \\
& Batak & 32,5 & 55,0 & 12,5 & $65,28 \pm 12,65$ & $40,00-97,78$ \\
& Bugis & 31,6 & 44,7 & 23,7 & $69,07 \pm 13,76$ & $37,78-8,89$ \\
\hline
\end{tabular}

Pendidikan Orang Tua . Pendidikan ayah dan ibu tertinggi pada responden Suku Jawa masing-masing sebesar 29,8 persen dan 31,5 persen yaitu pada jenjang $\mathrm{S} 1$. Sebanyak tiga dari sepuluh responden Suku Batak memiliki ayah dengan jenjang $\mathrm{S} 1$ sedangkan 35,0 persen ibu adalah tamat SMA. Selanjutnya, pada responden Suku Bugis, lebih dari separuh ayah berada pada jenjang $S 1(57,9 \%)$ dan 31,6 persen juga berada pada jenjang S1. Secara keseluruhan, sebagian besar pendidikan terakhir ayah merupakan lulusan S1 dengan persentase sebesar 35 persen sementara pendidikan ibu didominasi oleh lulus SMA sebanyak 31,5 persen dan sedikit persentasenya yaitu ibu tidak tamat SMA $(0,3 \%)$ dan ayah tidak lulus SMP $(0,7 \%)$.

Pekerjaan Orang Tua. Pekerjaan ayah responden Suku Jawa terbanyak adalah wiraswasta dengan persentase sebesar 29,8 persen dan sebanyak separuh $(50,0 \%)$ ibu responden Suku Jawa adalah ibu rumah tangga (IRT). Sementara pada Suku Batak lebih dari satu per tiga $(31,3 \%)$ ayah dari responden Suku Batak merupakan wiraswasta dan separuh (50,0\%) ibu adalah IRT. Selanjutnya, pada Suku Bugis, kurang dari 40 persen $(39,5 \%)$ ayah yakni PNS/POLRI/TNI/Guru dengan pekerjaan ibu responden Suku Bugis, sebanyak 47,4 persen berada pada golongan PNS/POLRI/TNI/Guru. Hasil secara keseluruhan menunjukkan, pekerjaan ayah didominasi oleh wiraswasta sebanyak 30,1 persen dan yang paling sedikit yaitu buruh sebanyak 0,1 persen. Sebanyak 5 dari 10 ibu yaitu ibu rumah tangga (48,3\%) dan jumlah pekerjaan ibu terendah yaitu sebagai dokter sebanyak satu persen.

\section{Kepribadian}

Deskripsi indikator kepribadian berdasarkan suku, dapat diketahui bahwa proporsi responden Suku Bugis yang memiliki kepribadian ekstrover paling besar dibandingkan Suku Jawa dan Batak yaitu sebesar 84,2 persen (Tabel 1). Responden dari Suku Jawa memiliki kepribadian ekstrover dengan proporsi 76,8 persen dan Suku Batak memiliki proporsi paling rendah yakni sebesar 63,8 persen. Kepribadian ekstrover yang dimiliki Suku Batak ini dibuktikan melalui rasa senang bertemu orang baru dan bergaul dengan orang lain dibanding Suku Jawa dan Suku Bugis. Sementara itu, responden dari Suku Batak memiliki persentase kepribadian intover paling tinggi sebesar 36,3 persen. Meskipun persentase proporsi responden dari Suku Batak dengan kepribadian introver masih lebih kecil dibandingkan responden dari suku tersebut dengan kepribadian ekstrover. Responden dari Suku Batak cenderung dicirikan oleh suatu keadaan bahwa apabila dalam keadaan tidak ada yang perlu disampaikan, responden Suku Batak akan memilih untuk diam atau sedikit berbicara. Termasuk dalam hal melakukan komplain. Responden yang berasal dari Suku Batak lebih memilih tidak membicarakan hal negatif suatu produk apabila belum merasakan sendiri kerugiannya.

Berdasarkan analisis butir pernyataan dalam penelitian menemukan, sekitar 90,0 persen Suku Jawa menjawab senang mencari teman baru dan senang bergaul dengan orang lain dan hanya satu per tiga $(31,0 \%)$ responden Suku Jawa yang senang bekerja di belakang panggung. Lebih dari tiga per empat responden Suku Batak juga senang bergaul dengan orang lain, senang mencari teman baru, menyukai banyak kegiatan/aktivitas ramai di sekitar, dan penuh semangat Selanjutnya, diatas 90 persen responden Suku Bugis senang bertemu orang-orang baru, senang mencari teman baru, dan membuat kegiatan yang membosankan menjadi asyik. Suku Jawa dan Batak memang memiliki persentase yang hampir sama, akan tetapi Suku Batak memiliki persentase yang lebih tinggi pada kepribadian ekstrover. 
Tabel 3 Sebaran dan analisis deskriptif perilaku komplain berdasarkan suku

\begin{tabular}{|c|c|c|c|c|c|}
\hline Variabel & Suku & Rendah (\%) & Sedang (\%) & Tinggi (\%) & Rataan \pm Std Vin-Max \\
\hline \multirow[t]{3}{*}{ Voice Response } & Jawa & 38,1 & 55,4 & 6,5 & $59,21 \pm 18,68 \quad 0,00-100,00$ \\
\hline & Batak & 36,3 & 60,0 & 3,8 & $60,50 \pm 13,6126,67-100,00$ \\
\hline & Bugis & 52,6 & 39,5 & 7,9 & $56,14 \pm 18,83 \quad 0,00-100,00$ \\
\hline \multirow[t]{3}{*}{ Private Response } & Jawa & 75,0 & 17,9 & 7,1 & $47,52 \pm 20,73 \quad 0,00-100,00$ \\
\hline & Batak & 68,8 & 15,0 & 16,3 & $55,94 \pm 19,63 \quad 0,00-100,00$ \\
\hline & Bugis & 73,7 & 13,2 & 13,2 & $48.68 \pm 23.37 \quad 0,00-100,00$ \\
\hline \multirow[t]{3}{*}{ Third Party Response } & Jawa & 89,9 & 8,9 & 1,2 & $26,83 \pm 21,64 \quad 0,00-100,00$ \\
\hline & Batak & 2,5 & 85,0 & 12,5 & $31,41 \pm 23,34 \quad 0,00-100,00$ \\
\hline & Bugis & 92,1 & 7,9 & 2,5 & $28,42 \pm 21,73$ \\
\hline \multirow[t]{3}{*}{ Perilaku komplain } & Jawa & 97,0 & 2,4 & 0,6 & $37,21 \pm 12,32$ \\
\hline & Batak & 80,0 & 16,3 & 3,8 & $48,81 \pm 14,7021,43-100,00$ \\
\hline & Bugis & 92,1 & 7,9 & 0,0 & $44,11 \pm 14,14$ \\
\hline
\end{tabular}

Hasil tersebut menggambarkan, responden dari ketiga suku dalam penelitian ini menyukai kegiatan yang berhubungan dengan orang lain. Temuan ini juga mengindikasikan, responden dari ketiga suku yang diteliti dalam penelitian ini akan dengan mudah menyampaikan keluh kesahnya pada orang lain baik kerabat, keluarga, maupun teman; termasuk yang terkait dengan komplain atas produk/jasa yang dikonsumsinya. Hasil uji beda kepribadian berdasarkan suku menunjukkan, tidak ada perbedaan signifikan antara kepribadian dengan masing-masing suku. Artinya, semua suku cenderung sama saja kepribadiannya, yakni memiliki kepribadian yang cenderung ekstrover.

\section{Motivasi}

Motivasi secara umum dengan persentase terbanyak $(56,5 \%)$ terdapat pada masyarakat Suku Jawa dan berada pada kategori sedang, dan persentase terbesar pada kategori tinggi yakni Suku Bugis sebesar 23,7 persen. Berdasarkan nilai rata-rata, Suku Bugis juga memiliki rataan paling besar dibanding kedua suku yang lain yakni 69,07 . Variabel motivasi memiliki dua dimensi yakni motivasi komplain dan motivasi tidak melakukan komplain, masing-masing dari dimensi ini memiliki indikator pertanyaan yang mendukung dan menggunakan skala likert, sehingga pada motivasi tidak melakukan komplain jawaban responden tidak harus di invers terlebih dahulu ketika akan menghitungnya. Motivasi komplain dari ketiga suku memiliki persentase terbesar pada kategori sedang, dan persentase terbanyak dimiliki oleh Suku Bugis sebesar 60,5 persen. Sementara pada kategori tinggi, persentase terbesar diperoleh Suku Jawa yakni 10,7 persen. Suku Jawa lebih banyak termotivasi untuk meminta penjelasan kepada pelaku usaha dibandingkan kedua suku lainnya, meskipun demikian rataan tertinggi diperoleh Suku Bugis sebesar 65,56. Pada motivasi tidak melakukan komplain dari ketiga suku yakni Suku Jawa, Batak, dan Bugis secara keseluruhan memiliki persentase lebih dari sembilan puluh persen berada pada kategori rendah, dan motivasi tidak komplain pada kategori tinggi diperoleh Suku Batak sebesar 1,3 persen. Berdasarkan deskripsi indikator, alasan konsumen tidak memiliki motivasi komplain karena merasa sudah terlambat dalam melakukan komplain (Tabel 2).

\section{Perilaku Komplain}

Variabel perilaku komplain terbagi menjadi tiga dimensi, yaitu voice response, private response, dan third party response. Perilaku komplain konsumen dapat dilihat melalui seberapa sering konsumen melakukan komplain, kapan terakhir komplain, jenis barang dan/atau jasa yang dikomplain, respon dari pelaku usaha, dan berapa lama pelaku usaha memberikan respon terhadap komplain.

Secara keseluruhan, lebih dari separuh $(67,9 \%)$ responden melakukan komplain kurang dari tiga kali selama satu tahun terakhir. Komplain terendah yang paling sedikit dilakukan oleh responden adalah lebih dari 10 kali dalam satu tahun terakhir yaitu hanya ditemukan pada 1,4 persen responden. Selain itu, sebanyak tiga dari sepuluh responden $(36,2 \%)$ melakukan komplain antara dua sampai empat bulan yang lalu. Hasil lain juga menunjukkan bahwa lebih dari setengah responden merasa kecewa ketika mengonsumsi barang $(67,2 \%)$ dan jasa $(32,4 \%)$. Barang yang paling sering dikomplain yaitu pakaian dengan persentase sebesar 29,4 persen. Sementara itu, jasa yang paling sering dikomplain responden yaitu transportasi dengan persentase sebesar 20,6 persen.

Selanjutnya, sebanyak enam dari sepuluh responden menyatakan bahwa pelaku usaha 
tetap ramah dan tetap melayani dengan baik meskipun responden telah menyampaikan komplain. Selain itu, 36,6 persen responden mendapatkan respon atas penyampaian komplainnya dalam hitungan hari saja; 8,7 persen responden tidak ditanggapi; dan 1 persen responden tidak diberikan kepastian atau respon lebih lanjut dari pelaku usaha. Penelitian ini juga menemukan bahwa hampir separuh responden $(42,9 \%)$ menyampaikan komplainnya melalui customer service karena dianggap sebagai cara mudah dalam menyampaikan komplain dibandingkan dengan menyampaikan kepada pelaku usaha secara langsung.

Perilaku komplain yang dilakukan Suku Jawa $(97,0 \%)$, Batak $(80,0 \%)$, dan Suku Bugis $(92,1 \%)$ sebagian besar berada dalam kategori hampir tidak pernah. Enam dari sepuluh responden Suku Batak lebih menyukai menyampaikan komplain melalui voice response $(60,0 \%)$ dan berada pada kategori jarang. Voice response yang banyak dilakukan Suku Batak yakni dengan cara menghubungi call center, costumer service, layanan pengaduan konsumen pada toko tersebut. Selanjutnya, lebih dari separuh responden dari ketiga suku termasuk dalam kategori hampir tidak pernah dalam melakukan private response. Suku Batak cenderung lebih berani melaporkan kekecewaannya kepada lembaga yang berwenang yang ditunjukkan dari sekitar 80 persen responden Suku Batak termasuk kedalam kategori jarang dalam melakukan perilaku komplain third party response. Tindakan third party response yang paling banyak dilakukan responden Suku Batak yakni melapor kepada lembaga perlindungan konsumen untuk memperingatkan konsumen lain. Suku Batak memiliki rata-rata terbesar dalam melakukan perilaku komplain dengan nilai 48,81 . Nilai rataan terbesar pada dimensi voice response dengan nilai sebesar 60,5, private response sebesar 55,94 , dan third party response sebesar 31,41 juga dimiliki oleh Suku Batak (Tabel 3).

Hasil uji beda dari tiga suku yaitu Suku Jawa, Batak, dan Bugis menunjukkan terdapat perbedaan yang signifikan antara perilaku komplain Suku Jawa dan Suku Batak $(\mathrm{sig}=0,023)$. Perilaku komplain Suku Batak lebih tinggi daripada Suku Jawa. Selain itu juga ditemukan adanya perbedaan yang signifikan antara Suku Jawa dan Suku Batak pada dimensi private response $(\mathrm{sig}=0,003)$ yang mana Suku Batak lebih tinggi dalam melakukan private response dibandingkan Suku Jawa dan Suku Bugis.
Voice Response. Hasil penelitian menemukan, sebanyak delapan dari sepuluh responden memilih menghubungi call center, costumer service, dan layanan pengaduan konsumen pada toko tersebut. Cara tersebut dianggap lebih mudah dan nyaman untuk melakukan komplain langsung kepada pelaku usaha. Temuan ini mengindikasikan, ketersediaan call center, costumer service, dan layanan pengaduan dianggap penting untuk dimiliki setiap pelaku usaha. Persentase paling rendah pada variabel voice response terdapat pada indikator menyampaikan keluhan atau kekecewaan terhadap produk yang dibeli hanya saat pelaku usaha meminta pendapat yaitu sebesar 45,1 persen. Konsumen merasa perlu untuk menyampaikan keluhannya ketika mengalami ketidakpuasan setelah mengonsumsi barang dan/atau jasa walaupun sebelumnya tidak diminta pendapat oleh pelaku usaha terlebih dahulu.

Private Response. Hasil penelitian menemukan, sebanyak tujuh dari sepuluh responden merasa sesuai untuk memberi tahu teman dan kerabat tentang pengalaman buruk yang dialami disebabkan oleh ketidakpuasan dalam mengonsumsi barang dan/atau jasa. Hal demikian dilakukan untuk menginformasikan kekesalan yang sedang dirasakan dengan harapan agar teman dan kerabat tidak mengalami hal serupa.

Third Party Response. Penelitian ini menemukan, sebanyak 23 persen responden merasa sesuai dengan pernyataan menyampaikan komplain kepada lembaga perlindungan konsumen dari pada melalui jalur lainnya. Hal tersebut dilakukan konsumen dengan tujuan pelaku usaha jera dalam melakukan kecurangan dan agar mendapat teguran langsung dari lembaga yang berwenang.

Tabel 4 Hubungan antara kategori kepribadian dengan kategori motivasi dan perilaku komplain

\begin{tabular}{lcc}
\hline \multirow{2}{*}{ Kategori Motivasi } & \multicolumn{2}{c}{ Kategori Kepribadian } \\
\cline { 2 - 3 } & Ekstrover (\%) & Introver (\%) \\
\hline Rendah & 28,0 & 32,9 \\
Sedang & 58,0 & 45,6 \\
Tinggi & 14,0 & 21,5 \\
\hline Sig. & \multicolumn{2}{c}{0,13} \\
\hline Kategori Perilaku & \multicolumn{2}{c}{ Kategori Kepribadian } \\
Komplain & Ekstrover (\%) & Introver (\%) \\
\hline Rendah & 86,0 & 87,3 \\
Sedang & 12,6 & 10,1 \\
Tinggi & 1,4 & 2,5 \\
\hline Sig. & 0,71 \\
\hline
\end{tabular}


Tabel 5 Faktor-faktor yang memengaruhi perilaku komplain berdasarkan suku

\begin{tabular}{lcccccc}
\hline Jalur & \multicolumn{2}{c}{ Jawa } & \multicolumn{2}{c}{ Batak } & \multicolumn{2}{c}{ Bugis } \\
\cline { 2 - 7 } & B & Ket & B & Ket & B & Ket \\
\hline Kepribadian $\rightarrow$ Perilaku Komplain & 0,05 & Tolak H2 & 0,13 & Tolak H2 & $0,466^{* *}$ & Terima H2 \\
Kepribadian $\rightarrow$ Motivasi & $-0,05$ & Tolak H3 & 0,13 & Tolak H3 & 0,26 & Tolak H3 \\
Motivasi $\rightarrow$ Perilaku Komplain & $0,73^{* *}$ & Terima H4 & $-0,10$ & Tolak H4 & 0,13 & Tolak H4 \\
\hline
\end{tabular}

Keterangan: $B$ : Beta; ' signifikan pada $p<0,01 ;{ }^{\prime}$ signifikan pada $p<0,05$

\section{Hubungan Kepribadian, Motivasi dan Perilaku Komplain}

Uji tabulasi silang digunakan untuk menganalisis besar hubungan kepribadian introver dan ekstrover dengan variabel motivasi dan perilaku komplain yang dikategorikan berdasarkan rendah, sedang, dan tinggi. Berdasarkan hasil analisis dapat diketahui bahwa tidak terdapat hubungan yang signifikan antara kepribadian dan motivasi serta antara kepribadian dengan perilaku komplain.

Tabel 4 menunjukkan bahwa sebesar 58 persen kepribadian ekstrover memiliki motivasi sedang. Pada kategori tinggi, kepribadian introver memiliki persentase lebih besar daripada ekstrover dengan nilai sebesar 21,5 persen. Dilihat dari nilai signifikansinya, hubungan kepribadian dengan motivasi menunjukkan hasil yang tidak signifikan yakni $0,130(\geq 0,05)$.

Tabel 4 menyajikan hasil analisis hubungan kepribadian introver dan ekstrover dengan perilaku komplain. Kepribadian introver memiliki persentase terbesar pada perilaku komplain kategori rendah $(87,3 \%)$, dan pada kategori tinggi, persentase kepribadian introver lebih besar $(2,5 \%)$ daripada kepribadian ekstrover (1,4\%). Meskipun demikian, hubungan kepribadian dengan perilaku komplain yang disajikan pada Tabel 4 dinyatakan tidak signifikan dengan nilai chi square sebesar 0,710 .

\section{Pengaruh Kepribadian dan Motivasi terhadap Perilaku Komplain berdasarkan Suku}

Berdasarkan model SEM yang diajukan dalam penelitian ini, dilakukan pengujian terhadap hipotesis. Pengujian hipotesis dapat dilihat melalui nilai $p$-value. Apabila nilai dari $p$-value lebih kecil dari atau sama dengan 0,05 maka pengaruh antar variabel dapat dikatakan signifikan. Namun, jika nilai p-value lebih besar dari 0,05 maka pengaruh antar variabel termasuk dalam kategori tidak signifikan (Tabel 5).
Pengaruh Kepribadian terhadap Perilaku Komplain. Berdasarkan hasil analisis model SEM, responden yang berasal dari Suku Jawa, Batak, dan Bugis yang disajikan pada Tabel 5. Selanjutnya, hasil penelitian berdasarkan Suku Jawa, Batak, maupun secara keseluruhan tidak mendukung hipotesis bahwa variabel kepribadian berpengaruh signifikan terhadap perilaku komplain. Berbeda dengan hasil analisis model SEM Suku Bugis. Pengaruh variabel kepribadian terhadap perilaku komplain pada Suku Bugis memiliki nilai $p$ value lebih kecil atau sama dengan 0,05 .

Pengaruh Kepribadian terhadap Motivasi. Pada model SEM yang dihasilkan dalam penelitian ini (Tabel 5), responden yang berasal dari Suku Jawa, Batak, dan Bugis memiliki koefisien pengaruh variabel kepribadian terhadap motivasi memiliki nilai $p$ value diatas 0,05 yang menandakan bahwa kepribadian tidak berpengaruh signifikan terhadap variabel motivasi. Berdasarkan sebaran analisis deskriptif hampir separuh responden memiliki kepribadian ekstrover yang terkategori tinggi dan separuh responden memiliki motivasi dalam kategori sedang. Artinya responden yang memiliki kepribadian ekstrover belum tentu termotivasi untuk menyampaikan keluhannya apabila mengalami kekecewaan atau kerugian pasca melakukan pembelian.

Pengaruh Motivasi terhadap Perilaku Komplain. Model SEM selanjutnya menguji hipotesis dengan hasil uji menunjukkan pengaruh variabel motivasi terhadap perilaku komplain Suku Jawa berpengaruh positif dengan nilai $p$-value lebih kecil dari 0,05 (Tabel 5). Hal ini mengindikasikan bahwa semakin tinggi motivasi yang dimiliki akan menyebabkan perilaku komplain yang semakin tinggi pula. Hasil model SEM Suku Batak, Suku Bugis, dan total menyatakan bahwa motivasi tidak berpengaruh signifikan terhadap perilaku komplain dengan nilai $\mathrm{p}$-value lebih besar dari 0,05. Berdasarkan deskripsi indikator, motivasi komplain terbanyak yaitu meminta penjelasan secara detail dari pelaku usaha, selanjutnya yakni mencari tindakan korektif, meminta produk baru, meminta uang kembali, dan mengungkapkan emosi atau 
kemarahannya kepada pelaku usaha. Motivasi responden tidak melakukan komplain terbesar yakni menganggap permasalahan tidak akan selesai meskipun telah melakukan komplain.

\section{PEMBAHASAN}

Berdasarkan hasil uji beda, terdapat perbedaan nyata antara Suku Jawa dan Batak dalam melakukan perilaku komplain. Masyarakat Suku Batak sangat menunjung tinggi martabat dan keadilan, untuk mewujudkan sikap tersebut Suku Batak akan dengan berani untuk menyampaikan komplainnya secara langsung kepada pelaku usaha ketika merasa dirugikan saat mengonsumsi barang dan/atau jasa (Ndona, 2018). Menurut Darmoko (2011) selain memiliki mental rendah hati, masyarakat Suku Jawa memiliki toleransi yang tinggi. Perseteruan atau adu mulut yang dilakukan masyarakat suku jawa hanya dilakukan jika masalah sudah memuncak, begitupula dalam hal komplain, jika tidak, permasalahan pembelian dianggap 'sepele' akan lebih baik diam dan tidak melakukan komplain secara langsung. Penelitian ini sejalan dengan pendapat Liu dan McLure (2001) bahwa budaya memiliki pengaruh dalam mengambil tindakan komplain. Suku Bugis merupakan suku yang menjunjuk tinggi nilai siri' dan pacce, yang artinya menjunjung harga diri dan harkat martabat namun mudah memaafkan dan berempati pada kesusahan orang lain. Kerugian-kerugian kecil yang dialami konsumen Suku Bugis mudah dimaafkan sehingga konsumen jarang melanjutkan untuk melakukan perilaku komplain (Syarif, Sumarmi, Fatchan, \& Astina, 2016). Meskipun demikian, pada variabel motivasi komplain Suku Bugis memiliki rata-rata paling tinggi diantara Suku Batak dan Jawa. Hal tersebut yang membedakan meskipun motivasi komplain Suku Bugis tinggi akan tetapi perilaku komplain yang dilakukan tidak setinggi Suku Batak.

Hasil penelitian pada Suku Jawa dan Batak tidak mendukung $\mathrm{H} 2$ bahwa variabel kepribadian berpengaruh signifikan terhadap perilaku komplain. Artinya, kepribadian tidak dapat memengaruhi konsumen untuk melakukan komplain khususnya pada Suku Jawa dan Batak. Temuan ini dimungkinkan karena kepribadian responden dalam penelitian ini cenderung homogen. Hasil uji beda kepribadian berdasarkan suku menunjukkan tidak ada perbedaan signifikan antara kepribadian dengan masing-masing suku. Artinya, semua suku cenderung sama saja kepribadiannya, yaitu relatif pada kepribadian ekstrover. Jika dibandingkan dengan penelitian sebelumnya, hasil ini tidak sejalan dengan Snitz, Weissferld, Cohen, dan Nebes (2015) yang mengungkapkan bahwa ciri kepribadian dan kontrol diri berhubungan dengan sikap konsumen dan kecenderungan untuk melakukan komplain. Demikian pula dengan Mat dan Said (2012) yang mengungkapkan bahwa kepribadian memiliki hubungan dengan kemampuan responden dalam melakukan komplain. Berbeda dengan hasil analisis model SEM Suku Bugis yang menemukan adanya pengaruh variabel kepribadian terhadap perilaku komplain dengan nilai $\mathrm{p}$-value lebih kecil atau sama dengan 0.05. Hal demikian menandakan bahwa kepribadian berpengaruh signifikan terhadap perilaku komplain pada Suku Bugis. Hasil ini sejalan dengan H2 bahwa kepribadian berpengaruh signifikan terhadap perilaku komplain.

Hasil uji pengaruh menunjukkan tidak terdapat pengaruh antara kepribadian terhadap motivasi. Artinya, kepribadian konsumen yang berbeda tidak membuat konsumen termotivasi untuk melakukan komplain. Hal ini dimungkinkan oleh kepribadian responden dalam penelitian ini yang cenderung tidak berbeda atau homogen yaitu secara keseluruhan cenderung lebih memiliki kepribadian ekstrover, dan motivasi yang dimiliki ketiga suku secara keseluruhan masuk kedalam kategori sedang. Motivasi adalah suatu keadaan dalam diri individu yang menyebabkan seseorang melakukan kegiatan tertentu untuk mencapai tujuan (Hamalik, 2001). Sutikno (2007) berpendapat bahwa motivasi berpangkal dari kata motif yang dapat diartikan sebagai daya penggerak yang ada didalam diri seseorang untuk melakukan aktivitas-aktivitas tertentu demi tercapainya suatu tujuan. Bahkan motif dapat diartikan sebagai suatu kondisi internal (kesiapsiagaan). Hasil penelitian ini kurang sejalan dengan hasil penelitian Corr dan Krupić (2017) dan Tillema dan Koppen (2012). Hasil Corr dan Krupić Krupic (2017) menunjukkan bahwa kepribadian responden akan memotivasi responden dalam mencari saluran untuk menyampaikan komplainnya kepada pelaku usaha. Kepribadian berbeda akan termotivasi untuk melakukan komplain yang berbeda pula, konsumen ekstrover cenderung memutuskan memberitahu teman atau kerabat ketika mengalami kekecewaan, sementara introver akan lebih termotivasi untuk melakukan komplain secara privat melalui surat elektronik kepada pelaku usaha. Penelitian Tillema dan 
Koppen (2012) mengatakan bahwa kepribadian seseorang akan berpengaruh nyata terhadap motivasi intrinsiknya dalam melakukan komplain.

Berdasarkan motivasi secara umum, kelompok suku Jawa dan Batak, tidak ada pengaruh motivasi terhadap perilaku komplain konsumen. Motivasi untuk komplain tidak serta merta membuat konsumen melakukan komplain. Namun untuk kelompok Suku Jawa, pengaruh motivasi terhadap perilaku komplain adalah signifikan. Artinya, motivasi yang tinggi akan mempengaruhi perilaku komplain yang semakin tinggi pula. Hasil penelitian pada kelompok Suku Jawa ini sejalan dengan Sutanto Gunawan, dan Thio (2017) yang juga menemukan bahwa motivasi berpengaruh dalam menyampaikan komplain untuk mengekspresikan emosi konsumen. Hasil penelitian tersebut juga sejalan dengan Nimako dan Mensah (2012) yang mengatakan bahwa motivasi memengaruhi konsumen untuk melakukan komplain atau tidak melakukan komplain. Bagi konsumen yang melakukan komplain, motif tertinggi adalah mencari tindakan korektif, diikuti dengan mencari penjelasan, mencari ganti rugi, meminta maaf, mengekspresi emosi atau kemarahan dan motif paling sedikit adalah mencari kompensasi atau kerusakan, motivasi konsumen tidak melakukan komplain beralasan karena sudah merasa terlambat melakukannya. Heung dan Lam (2003) pun mendukung hasil penelitian tersebut. Menurut penelitian Heung dan Lam (2003) motivasi konsumen dalam melakukan komplain ialah mencari perbaikan dalam segi produk dan pelayanan. Konsumen akan lebih menghargai bagi pelaku usaha yang bersedia menganggapi keluhannya dengan baik sehingga motivasi memiliki pengaruh dalam perilaku komplain konsumen. Pada penelitian ini, motivasi komplain masih terkategori sedang dan perilaku komplain terkategori rendah. Hu dan Kim (2018) menyatakan bahwa motivasi responden yang tinggi akan semakin menemukan kesempatan untuk melakukan perilaku komplain. Oleh karena itu, peningkatan motivasi dibutuhkan untuk dapat meningkatkan perilaku komplain.

\section{SIMPULAN DAN SARAN}

Tipe kepribadian ketiga suku yakni Suku Jawa, Bugis, dan Batak lebih dominan pada ekstrover, motivasi terbanyak pada ketiga suku termasuk kedalam kategori sedang, dan perilaku komplain yang dilakukan oleh responden dari ketiga suku juga terkategori rendah. Hasil rata-rata yang dibedakan berdasarkan suku menunjukkan bahwa Suku Bugis memiliki rata-rata motivasi komplain paling tinggi diantara ketiga suku. Suku Batak memiliki rata-rata perilaku komplain paling tinggi diantara Suku Jawa, Suku Batak, dan Suku Bugis. Selain itu, juga ditemukan adanya perbedaan nyata antara Suku Jawa dan Suku Batak dalam melakukan perilaku komplain. Perbedaan yang signifikan juga ditemukan antara Suku Jawa dan Suku Batak pada dimensi private response. Hasil analisis model SEM yang dibuat berdasarkan suku, membuktikan bahwa terdapat pengaruh signifikan antara kepribadian terhadap perilaku komplain Suku Bugis. Namun tidak terdapat pengaruh signifikan antara kepribadian terhadap motivasi dari model SEM tiap-tiap suku maupun total. Lebih lanjut, ditemukan adanya pengaruh signifikan motivasi terhadap perilaku komplain pada model SEM Suku Jawa, namun tidak ada pengaruh signifikan pada Suku Batak, dan Suku Bugis.

Berdasarkan hasil penelitian, motivasi ketiga suku termasuk kedalam kategori sedang sehingga diharapkan konsumen khususnya yang berasal dari Suku Jawa, Suku Batak, dan Suku Bugis perlu meningkatkan motivasi komplain dalam dirinya mengingat masih banyak konsumen yang menjawab permasalahan tidak akan selesai meskipun telah melakukan komplain. Berdasarkan hasil penelitian, motivasi berpengaruh terhadap perilaku komplain. Hal demikian pun berdampak pada perilaku komplain yang rendah terutama pada dimensi third party response terutama pada Suku Jawa. Sebagai konsumen yang cerdas diperlukan kesadaran untuk mengetahui hak dan kewajiban konsumen sebagaimana yang telah tercantum dalam Pasal 4 dan Pasal 5 Undang-Undang No 8 Tahun 1999. Proses pengambilan data dalam penelitian ini dilakukan dengan metode survei online sehingga peneliti tidak dapat melihat secara langsung proses pengisian kuesioner. Bagi peneliti selanjutnya dapat menggunakan teknik pengambilan data serta melakukan wawancara mendalam untuk memperkaya hasil penelitian.

\section{DAFTAR PUSTAKA}

Blodgett, J. G., Bakir, A., Saklai., A \& Bhaskar, S. (2015). Customer complaint behavior: an examination of cultural vs. Situational factors. Journal of Consumer Satisfaction/ Dissatisfaction and Complaining Behavior, 8(1), 61-70. 
[BPS] Badan Pusat Statistik. (2017). Survei Penduduk 2010: Jumlah dan Presentase Penduduk Suku Bangsa. Tersedia pada https://www.bps.go.id/

Briones, A, E., Cockx, L., \& Swinnen, J. (2018). Culture and food security. Global Food Security, 17, 113-127. doi:10.1016/j.gfs.2018.02.002.

Cahyaning, S., \& Cahyono, A. (2015). Perbedaan communication privacy management di media sosial twitter pada remaja dengan tipe kepribadian ekstrovert dan introvert. Jurnal Psikologi Pendidikan dan Perkembangan, 4(1), 65-70.

Corr, P. J., \& Krupić, D. (2017). Motivating personality. Journal of advances in Motivation Science, 2(2), 39-90. doi:10.1016/bs.adms.2017.02.003.

Darmoko, P. (2011). Budaya Jawa Dalam Diaspora. Jurnal IImu Seni dan Budaya. 1(1), 1-12.

Ekinci, Y., Calderon, J., \& Siala, H. (2016). Do personality traits predict 'complaining' consumers? Journal of Business Environment, 8 (1). p. 32. DOI: 10.1504/IJBE.2016.074793

Hamalik, O. (2001). Proses Belajar Mengajar. Jakarta, ID: PT. Bumi Aksara.

Hartoyo, Tinaprila, N., \& Prasetyo, A. (2016). Behaviour analysis of consumer complain. Journal of Business and Entrepreneurship. 2(2). 60-72. doi: 10.17358/IJBE.2.2.101.

Heung, V., \& Lam. (2003). Customer complaint behaviour towards hotel restaurant services. International Journal Contemporer Hospital Manage, 15(5), 283-289.

doi.org/10.1108/09596110310482209.

Hu, Y., \& Kim, H. J. (2018). Positive and negative ewom motivations and hotel customers' ewom Behavior: Does personality matter?. International Journal of Hospitality Management, 75 (1), 2737. doi.org/10.1016/j.ijhm.2018.03.004

Ibiduni, O., \& Iyiola, O. (2013). The relationship between complaints, emotion, anger, and subsequent behavior of customers. IOSR Journal of Humanities And Social Science (IOSR-JHSS), $\quad$ 17(6), 34-41. doi: 10.9790/0837-1763441.
Keng, K. A., Richmond, D., \& Han, S. (2015). Determinants of consumer complaint behaviour: A study of Singapore consumers. Journal of International Consumer Marketing, 8(2), 59-76. doi.org/10.1300/J046v08n02_05.

Liu, R., \& McLure, P. (2001). Recognizing cross-cultural differences in consumer complaint behavior and intentions: an empirical examination. Journal of Consumer Marketing, 10(1), 54-74. doi.org/10.1108/07363760110365813

Mat, A., \& Said, A. (2012). Factor affecting consumer complaint behaviour. Journal of Consumers, 18(2), 16-37.

Metehan, T., \& Yasemin, A. Z. (2011). Demographic characteristics and complaint behavior: an empirical study concerning Turkish customer. International Journal of Business and Social Science, 2(9), 42-48.

Ndona, Y. (2018). Kemanusiaan dalam falsafah hidup masyarakat Batak Toba. Jurnal Citizenship: Media Publikasi Pendidikan Pancasila dan Kewarganegaraan, 1(1), 15-22

Nimako, S., \& Mensah, A. (2012). Motivation for customer complaining and noncomplaining behaviour towards mobile telecommunication services. Asian Journal of Business Management. 4(3), 310-320.

Priporas, C. V., Stylos, N., \& Fotiadis, A. (2017). Generation $\mathrm{z}$ consumers expectatios of interactions smart retailing: A future agenda. Computer in Human Behavior Jornal. 71(1), 274- 383. doi.org/10.1016/j.chb.2017.01.058

Putra, N., \& Giantari, I. (2015). Pengaruh sikap mengeluh dan jenis kelamin terhadap perilaku komplain di Fakultas Ekonomi dan Bisnis Universitas Udayana Denpasar. E-Jurnal Manajemen Universitas Udayana, 3(9), 2471-2488.

Simanjuntak, M. (2015). Consumer Empowerment Index among Undergraduate Students of Bogor Agricultural University, Indonesia. Asian Journal of Business and Management. 3 / 3 : $183 \quad-191$. http://www.ajouronline.com/index.php/AJ BM/article/view/1538/1406 
Simanjuntak, M., \& Putri, S.A. (2018). Consumer empowerment index of electronic product buying. Independent Journal of Management \& Production. 9 (4), 1165-1183. http://www.ijmp.jor.br/index.php/ijmp/articl e/view/814

Simanjuntak, M., \& Siswanto. (2018). Coping strategies in consumer complaints. Prosiding. Makalah dipresentasikan pada 2018 International Conference on Industry, Business and Social Sciences (IBSS 2018). Penyelenggara : The global academic-industrial cooperation society (GAICS), Waseda University, Tokyo University, Auburn Montmogery. https://iconf-

my.sharepoint.com/personal/123_my_con f_tw/_layouts/15/onedrive.aspx?id=\%2Fp ersonal\%2F123_my_conf_tw\%2FDocume nts\%2FDownload\%2FIBSS_Full\%20Pape r\%2Epdf\&parent=\%2Fpersonal\%2F123 my_conf_tw\%2FDocuments\%2FDownloa d\&slrid=a7ec8f9e-405c-7000-4e043f98a33e165d

Simanjuntak, M., \& Hamimi, U.K. (2019). Penanganan komplain dan komunikasi Word-Of-Mouth (WOM). Jurnal IImu Keluarga dan Konsumen. 12(1), 75-86. http://dx.doi.org/10.24156/jikk.2019.12.1.7 5

Simanjuntak, M. (2019). Generation Y's complaint behavior toward online shopping. Independent Journal of Management \& Production. 10 (16), 101116.

http://dx.doi.org/10.14807/ijmp.v10i1.839
Snitz, B. E., Weissferld, L. A., Cohen, A. D., \& Nebes, R. D. (2015) Subjective Cognitive Complaints, Personality and Brain Amyloid-beta in Cognitively Normal Older Adults. Journal Psychiatry, 1 (1): 1-9, doi.org/10.1016/j.jagp.2015.01.008

Sumarwan, U. (2014). Perilaku Konsumen. Bogor ,ID: Ghalia Indonesia.

Sutanto, J., Gunawan, B., \& Thio, S. (2016). Perilaku dan motivasi komplain responden terhadap restoran- restoran di Surabaya, Jurnal manajemen, 2(1): 125138.

Sutikno, S. (2007). Peran guru dalam membangkitkan motivasi belajar siswa. Jurnal Pendidikan, 1(1):1-10.

Syarif, E., Sumarmi., Fatchan, A., Astina I. (2016). Integrasi nilai budaya etnis bugis makassar dalam proses pembelajaran sebagai salah satu strategi menghadapi era Masyarakat Ekonomi Asean (MEA). Jurnal Teori dan Praksis Pembelajaran IPS, 1(1), 1-21

Thogersen, J., Juhl, H. J., \& Poulsen, C. S. (2003). Complaining: a function of attitude, personality and situation. Journal American Association Marketing and Public Policy Conference, 11(3), 70-83.

Tillema, R., \& Koppen, S. (2012). Effect of formative feedback on intrisic motivation: Examining ethnic differences. Journal Learning and Individual Differences, 22(1),449-454. doi.org/10.1016/j.lindif.2012.04.001. 